\title{
Al-Chizan
}

ISSN 1907-0985, E ISSN 2442-8256

Vol. 16, No. 1, 2020, h. 1-26

DOI: https://doi.org/10.30603/am.v16i1.1405

\section{Eksistensi Bimbingan Perkawinan Pranikah di Wilayah Kecamatan Ujung Tanah Kota Makassar}

\author{
Ahmad Jazil \\ KUA Kecamatan Ujung Tanah Kota Makassar \\ Email: ahjaz588@gmail.com
}

\begin{abstract}
Pre-marital marriage cource aims to equip brides-to-be with understanding and knowledge and skills about married life, hoping that in the future they can create a harmonious family while reducing conflict, domestic violence and divorce. This study discusses the existence of pre-marital marriage course in the Ujung Tanah District, Makassar City. This study uses a qualitative approach with data collection methods through interviews. The results of this study indicate that participants of premarital marriage course in the Ujung Tanah District, Makassar city are participants who have registered at the Office of Religious Affairs, but have not yet entered into a marriage contract. The fact that after following pre-marital marriage course, the couples feel each other's self confidence increases and their are better prepared to live a domestic life, so that the existence of pre-marital marriage course can create a happy family. However, in the implementation there were also obstacles faced by the facilitators and the guidance participants.
\end{abstract}

Keywords: Marriage Course, Family, Happy, Office of Religious Affairs

\section{The Existence of Pre-Marital Marriage Course in the Territory Ujung Tanah District, Makassar City}

\begin{abstract}
Abstrak: Bimbingan perkawinan pranikah ini mempunyai tujuan untuk membekali para calon pengantin dengan pemahaman dan ilmu pengetahuan serta keterampilan tentang kehidupan berumah tangga, dengan harapan kedepannya mereka dapat menciptakan keluarga yang harmonis sekaligus dapat mengurangi terjadinya perselisihan, kekerasan dalam rumah tangga serta perceraian. Penelitian ini membahas eksistensi Bimbingan Perkawinan Pranikah di wilayah Kecamatan Ujung Tanah Kota Makassar. Penelitian ini menggunakan pendekatan kualitatif dengan menggunakan metode pengumpulan data melalui wawancara. Hasil penelitian ini menunjukkan bahwa peserta bimbingan perkawinan pranikah di wilayah Kecamatan Ujung Tanah Kota Makassar adalah peserta yang sudah mendaftar di Kantor Urusan Agama, namun belum melangsungkan akad nikah. Fakta yang ada setelah mengikuti bimbingan perkawinan pranikah, para pasangan merasa kepercayaan diri masing-masing meningkat dan lebih siap menjalani kehidupan rumah tangga, sehingga tampak eksistensi bimbingan perkawinan pranikah dapat menciptakan keluarga sakinah. Namun dalam pelaksanaannya juga terdapat kendala-kendala yang dihadapi bagi para fasilitator dan para peserta bimbingan.
\end{abstract}

Kata Kunci: Bimbingan Perkawinan, Keluarga, Sakinah, Kantor Urusan Agama 


\section{A. Latar Belakang}

Kehidupan bermasyarakat tidak bisa dipisahkan dengan interaksi antar sesama individu, baik itu persoalan privat maupun publik. Salah satu persoalan privat adalah persoalan perkawinan. Persoalan ini senantiasa menjadi aktual dan menarik untuk dibahas dikarenakan ini menyangkut tabiat dan hajat hidup manusia yang asasi, serta menyangkut sebuah kelembagaan yang suci dan luhur, yaitu kehidupan berumah tangga. Keluhuran ini karena menjadi benteng pertahanan bagi martabat kemanusiaan dan nilai-nilai akhlak bagi pelaku kehidupan rumah tangga tersebut.

Perkawinan secara filosofis dalam Islam menjadi bagian yang tidak terpisahkan dengan ajaran Islam. Hal ini dikarenakan perkawinan menjadi salah satu bentuk perintah kepada umat Islam yang memiliki kemampuan bagi seorang laki-laki dan seorang perempuan untuk menjalin ikatan suci sebagai pasangan suami isteri dalam bentuk perkawinan sah dalam rangka membentuk sebuah keluarga. Sebuah keluarga adalah sebuah komponen masyarakat terkecil yang terdiri suami, isteri dan anak. ${ }^{1}$

Perkawinan dalam Islam melalui hukum perkawinan sebagaimana yang ditentukan dalam Alquran bertujuan untuk mewujudkan keluarga sakinah, tenang, rukun dan damai agar nantinya terwujud pulalah masyarakat yang baik. Masyarakat yang baiklah, maka manusia akan memperoleh kebahagiaan, ketenteraman serta kedamaian di dunia, kemudian secara otomatis kebahagiaan, ketenteraman dan kedamaian duniawi akan mempunyai kelanjutan pula di akhirat kelak, ${ }^{2}$ tidak terkecuali dalam lingkup keluarga.

Keluarga adalah kelompok terkecil dalam masyarakat yang memiliki peran dan tanggungjawab dalam melestarikan keluarga. Membangun keluarga yang kokoh membutuhkan usaha yang sungguh-sungguh. Untuk mewujudkan keluarga yang demikian, maka sebaiknya terlebih dulu harus mendapatkan bimbingan perkawinan pra nikah.

Bimbingan perkawinan pranikah ini mempunyai tujuan untuk membekali para calon pengantin dengan pemahaman dan ilmu pengetahuan serta keterampilan tentang

\footnotetext{
${ }^{1}$ Rizal Darwis, Nafkah Batin Isteri dalam Hukum Perkawinan (Cet. 1; Gorontalo: Sultan Amai Press, 2015), 1.

${ }^{2}$ Harun Nasution, Islam Rasional (Cet. 5; Bandung: Mizan, 1998), 427.
} 
kehidupan berumah tangga, dengan harapan kedepannya mereka dapat menciptakan keluarga yang harmonis sekaligus dapat mengurangi terjadinya perselisihan, kekerasan dalam rumah tangga serta perceraian.

Hal ini dipertegas dengan terbitnya Keputusan Direktur Jenderal Bimbingan Masyarakat Islam Nomor 379 Tahun 2018 tentang Petunjuk Pelaksanaan Bimbingan Perkawinan Pranikah Bagi Calon Pengantin. ${ }^{3}$ Dengan terbitnya keputusan ini serentak dilaksanakan oleh semua provinsi di Indonesia, sesuai pada lampiran pada Keputusan Direktur Jenderal Bimbingan Masyarakat Islam Nomor 379 Tahun 2018 tentang Petunjuk Pelaksanaan Bimbingan Perkawinan Pranikah Bagi Calon Pengantin. Bimbingan ini dilaksanakan oleh Kementerian Agama Kabupaten/Kota, Kantor Urusan Agama Kecamatan atau lembaga lain.

Idealnya dengan adanya bimbingan perkawinan pranikah diharapkan pasangan suami istri yang ada di Kecamatan Ujung Tanah, keutuhan keluarga dalam masyarakat dapat meningkat. Namun kenyataannya sebahagian masyarakat yang sudah menikah dan mendapatkan bimbingan perkawinan pranikah masih menemukan kesulitan dalam membina keutuhan keluarga, sehingga keluarga yang terbentuk sangat jauh dari kata harmonis, bahkan masih ditemukan beberapa kasus perselisihan, kekerasan dalam rumah tangga dan perceraian. Tentu hal ini membutuhkan solusi baik oleh instansi yang menangani tentang bimbingan perkawinan pranikah maupun terhadap pasangan suami istri itu sendiri.

\section{B. Eksistensi Bimbingan Perkawinan Pranikah}

Kata bimbingan secara etimologis merupakan terjemahan dari bahasa Inggris yaitu guidance yang berasal dari kata kerja to guide yang mempunyai arti "menunjukkan, membimbing, menuntun ataupun membantu". Sesuai dengan istilahnya, secara umum bimbingan dapat diartikan sebagai suatu bantuan atau tuntunan. $^{4}$

\footnotetext{
${ }^{3}$ Kementerian Agama RI., Keputusan Direktur Jenderal Bimbingan Masyarakat Islam Nomor 379 Tahun 2018 tentang Petunjuk Bimbingan Perkawinan Pranikah Bagi Calon Pengantin.

${ }^{4}$ Suhertina, Pengantar Bimbingan dan Konseling di Sekolah (Pekanbaru: Suska Press, 2008), 1.
} 
Menurut M. Arifin bahwa bimbingan adalah menunjukkan, memberikan jalan atau menuntun orang lain kearah tujuan yang bermanfaat bagi kehidupan dimasa kini dan dimasa akan datang. ${ }^{5}$ Menurut Smith mengemukakan bimbingan adalah proses layanan yang diberikan kepada idividu guna membantu mereka dalam memperoleh pengetahuan dan keterampilan yang diperlukan dalam membuat pilihan-pilihan, rencana-rencana dan interpretasi-interpretasi yang diperlukan untuk menyesuaikan diri yang baik. ${ }^{6}$ Kesimpulannya bimbingan adalah proses transfer ilmu pengetahuan dan keterampilan yang sistimatis terhadap seseorang/kelompok guna mengembangkan potensi yang dimilikinya dalam upaya memperoleh kehidupan yang lebih baik.

Sedangkan pranikah adalah berasal dari kata pra dan nikah, pra merupakan awalan (prefiks) yang bermakna sebelum. ${ }^{7}$ Sedangkan Nikah adalah perjanjian antara laki-laki dan perempuan untuk bersuami istri (dengan resmi). ${ }^{8}$ Pranikah adalah waktu sebelum adanya akad nikah antara laki-laki dan perempuan, yang sah berdasarkan hukum syar'i dan hukum per-undang-undang perkawinan.

Dengan demikian bimbingan pranikah yang dimaksud dalam penelitian ini adalah pemberian bekal secara sistimatis berupa petunjuk, penasihatan, bimbingan serta pengarahan kepada calon pengantin sebelum melangsungkan akad nikah yang dilakukan oleh pembimbing/fasilitator.

Kegiatan bimbingan berperan untuk memberikan penasehatan dan penerapan mengenai nikah, serta bertujuan mengurangi meningkatnya angka perceraian dan kekerasan dalam rumah tangga khususnya kalangan muda, supaya orang tidak merasa salah menetapkan pilihannya atau tidak mengalami banyak kesulitan dalam penyesuaian diri kehidupan berkeluarga.

Walgito mengemukakan bahwa latar belakang perlunya bimbingan dan konseling perkawinan, antara lain:

${ }^{5}$ M.Arifin, Pedoman Pelaksanaan Bimbingan Penyuluh Agama (Jakarta: Golden Terayn Press, 1998), 1.

${ }^{6}$ Prayitno, dkk, Dasar-Dasar Bimbingan dan Konseling (Jakarta: PT Rineka Cipta, 1999), 14.

${ }^{7}$ Departemen Pendidikan dan Kebudayaan RI, Kamus Besar Bahasa Indonesia, (Jakarta: PN. Balai Pustaka, 1989), 697.

${ }^{8}$ Ibid., 614. 
1. Masalah perbedaan individu; Setiap individu mempunyai kemampuan unuk berpikir, namun bagaimana kualitas berpikirnya satu dengan yang lain akan berbeda-beda. Ada yang dapat memecahkan dengan cepat, tetapi yang lain dengan lambat, sedangkan yang lain lagi mungkin tidak dapat memecahkan masalah tersebut. Bagi individu yang tidak dapat memecahkan masalah yang dihadapinya, maka ia membutuhkan bantuan orang lain untuk ikut memikirkan dan memecahkan masalah yang dihadapinya, perlu bantuan orang lain atau bimbingan konseling.

2. Masalah kebutuhan individu; Manusia merupakan makhluk hidup yang mempunyai kebutuhan-kebutuhan tertentu. Kebutuhan merupakan pendorong timbulnya tingkah laku. Dalam perkawinan kadang-kadang justru sering individu tidak tahu harus bertindak bagaimana. Dalam hal seperti ini maka individu yang bersangkutan membutuhkan bimbingan dan konseling yang berperan membantu mengarahkan ataupun memberikan pandangan individu yang bersangkutan.

3. Masalah perkembangan individu; Individu merupakan makhluk yang berkembang dari masa ke masa. Akibat dari perkembangan yang ada pada individu akan mengalami perubahan-perubahan. Kadang-kadang individu mengalami hal-hal yang tidak mengerti khususnya dalam perkawinan. Akibatnya hal ini menimbulkan berbagai macam kesulitan, maka dari itu bimbingan dan konseling sangat diperlukan bantuan untuk pengarahannya.

4. Masalah latar belakang sosio-kultural; Perkembangan keadaan menimbulkan banyak perubahan dalam kehidupan masyarakat, seperti perubahan dalam aspek sosial, politik, ekonomi, industri, sikap, nilai dan sebagainya. Keadaan akan mempengaruhi kehidupan perkawinan individu, sehingga berbagai macam tantangan atau tuntutan terhadap kebutuhan individu. Dengan kata lain individu membutuhkan bimbingan dan konseling. ${ }^{9}$

Dengan adanya program bimbingan pra nikah yang diberikan kepada pasangan adalah untuk membantu memecahkan masalah atau informasi seputar perkawinan dan

\footnotetext{
${ }^{9}$ Bimo Walgito, Bimbingan dan Konseling Perkawinan (Yogyakarta: Penerbit Andi, 2000), 6-9.
} 
rumah tangga. Juga dengan mengikuti bimbingan maka efektifitas bimbingan tersebut dalam keluarga adalah menimbulkan kesadaran dari pasangan terhadap adanya hak dan tanggung jawab sebagai seorang suami dan istri, sehingga dalam kehidupan berumah tangga terbentuk sikap saling pengertian, saling menghargai.

Salah satu pendekatan yang digunakan dalam bimbingan pra nikah menurut Carl Rogers sebagaimana dikutip Mubasyorah adalah pendekatan humanistik yaitu sebagai person centered berorientasi monistik, artinya ia memandang manusia sebagai makhluk yang dilahirkan dengan pembawaan dasar yang baik, memiliki kecenderungan yang bertujuan positif, konstruktif, rasional, sosial, berkeinginan untuk maju, realistik, memiliki kapasitas untuk menilai diri dan mampu membawa dirinya untuk bertingkah laku sehat dan seimbang, cenderung berusaha untuk mengaktualisasikan diri, memperoleh sesuatu dan mempertahankannya. ${ }^{10}$

Adanya kegiatan bimbingan pranikah perkawinan ini didasarkan atas Peraturan Direktur Jenderal Bimbingan Masyarakat Islam No. DJ.491/11 Tahun 2009 tentang Kursus Calon Pengantin yang kemudian disempurnakan dengan Peraturan Direktur Jenderal Bimbingan Islam No. DJ.II/542 Tahun 2013 tentang Pedoman Penyelenggaraan Kursus Pra Nikah, Keputusan Direktur Jenderal Bimbingan Islam No.373/2017 tentang Petunjuk Teknis Bimbingan Perkawinan Bagi Calon Pengantin serta Keputusan Direktur Jenderal Bimbingan Masyarakat Islam Nomor 379 Tahun 2018 tentang Petunjuk Pelaksanaan Bimbingan Perkawinan Pranikah Bagi Calon Pengantin.

\section{Bimbingan Perkawinan Pranikah di Wilayah Kecamatan Ujung Tanah Kota Makassar}

Menurut Peraturan Direktur Jenderal Bimbingan Masyarakat Islam Nomor DJ.II/542 Tahun 2013 tentang Pedoman Penyelenggaraan Kursus Pra Nikah. ${ }^{11}$ Bimbingan perkawinan pranikah yang awalnya disebut kursus pra nikah adalah pemberian bekal pengetahuan, pemahaman, keterampilan dan penumbuhan kesadaran

\footnotetext{
${ }^{10}$ Mubasyorah, "Konseling Pra Nikah dalam Mewujudkan Keluarga Bahagia," Konseling Religi: Jurnal Bimbingan Konseling Islam, Vol. 7, No. 2, Desember 2016; 15.

${ }^{11}$ Kementerian Agama RI., Peraturan Direktur Jenderal Bimbingan Masyarakat Islam No. DJ.II/542 Tahun 2013 tentang Pedoman Penyelenggaraan Kursus Pra Nikah.
} 
kepada remaja usia nikah tentang kehidupan rumah tangga dan keluarga. ini dimaksudkan untuk meningkatkan pemahaman dan pengetahuan tentang kehidupan rumah tangga/keluarga dalam mewujudkan keluarga sakinah, mawaddah warahmah serta mengurangi angka perselisihan, perceraian, dan kekerasan dalam rumah tangga.

Menikah di usia yang belum matang berpengaruh dalam kehidupan berumah tangga akan tetapi ada usaha yang dapat dilakukan dalam meningkatkan kematangan emosional dalam berkeluarga. Usaha tersebut dilakukan baik oleh perseorangan maupun dalam bentuk suatu badan lembaga. ${ }^{12}$

Penyelenggara pada bimbingan perkawinan pranikah bagi calon pengantin adalah Kementerian Agama Kabupaten/Kota, Kantor Urusan Agama Kecamatan dan Lembaga lainnya yang telah memenuhi persyaratan dan mendapat izin penyelenggara dari Kementerian Agama sesuai dengan tingkat kewenangan yang ditetapkan oleh Kementerian Agama. ${ }^{13}$

Berdasarkan hal tersebut di atas, maka pelaksanaan bimbingan perkawinan pranikah bagi calon pengantin bagi masyarakat di wilayah Kecamatan Ujung Tanah Kota Makassar dipusatkan di Aula Kantor Kementerian Agama Kota Makassar dari seluruh Kecamatan yang ada di Kota Makassar. Target peserta yang disyaratkan yaitu 25 pasang dalam satu angkatan, sehingga untuk memenuhi target yang dimaksud maka digabunglah seluruh Kecamatan yang ada di wilayah Kota Makassar.

Peserta bimbingan perkawinan pranikah kurang dari 50 orang ayau 25 pasang, pelaksanaannya dapat digabung dengan beberapa kecamatan dan dikoordinasikan oleh Kepala Seksi Bimas Islam Kabupaten/Kota setempat sejalan dengan Keputusan Direktur Bimbingan Islam No. 379 Tahun 2018 tentang Petunjuk Pelaksanaan Bimbingan Perkawinan Pranikah Bagi Calon Pengantin bahwa dalam hal mekanisme mengikuti bimbingan perkawinan pranikah terlebih dahulu mendaftarkan pernikahannya di Kantor Urusan Agama Kecamatan setelah dilakukan pemeriksaan berkas dan dinyatakan berkas administrasi pernikahannya memenuhi persyaratan, maka

\footnotetext{
${ }^{12}$ Nofiyanti, "Layanan Bimbingan Pra Nikah dalam Meningkatkan Kematangan Emosional Berkeluarga,” Prophetic, Vol. 1, No. 1, November 2018; 129.

${ }^{13}$ Kementerian Agama RI., Keputusan Direktur Jenderal Bimbingan Masyarakat Islam Nomor 379 Tahun 2018 tentang Petunjuk Pelaksanaan BImbingan Pranikah Bagi Calon Pengantin.
} 
calon pengantin akan diberikan undangan untuk mengikuti bimbingan perkawinan pranikah. ${ }^{14}$

1. Petunjuk Pelaksanaan Bimbingan Perkawinan Pranikah

Berdasarkan Keputusan Direktur Jenderal Bimbingan Masyarakat Islam Nomor 379 Tahun 2018 tentang Petunjuk Pelaksanaan Bimbingan Perkawinan Pranikah Bagi Calon Pengantin, sebagai berikut:

a. Pengorganisasian

Pelaksanaan bimbingan perkawinan pranikah bagi calon pengantin diawali dengan pengorganisasian, yaitu:

(1) Penyelenggara bimbingan perkawinan pranikah bagi calon pengantin adalah: a) Kementerian Agama Kabupaten atau Kota; b) Kantor Urusan Agama Kecamatan; c) Lembaga lain yang telah memenuhi persyaratan dan mendapat izin penyelenggaraan dari Kementerian Agama sesuai dengan tingkat kewenangan yang ditetapkan Kementrian Agama;

(2) Koordinator teknis penyelenggaraan bimbingan perkawinan pranikah bagi calon pengantin adalah Kepala Seksi yang membidangi Urusan Agama Islam/Bimbingan Masyarakat Islam pada Kantor Kementerian Agama Kabupaten/Kota;

(3) Bimbingan perkawinan pranikah bagi calon pengantin diprioritaskan untuk calon pengantin yang telah terdaftar di KUA Kecamatan;

(4) Dalam hal yang tidak terdapat calon pengantin yang mendaftar, maka bimbingan perkawinan dapat diberikan kepada remaja yang telah memasuki usia 21 tahun;

(5) Bimbingan perkawinan pranikah bagi calon pengantin berpedoman pada buku modul bimbingan perkawinan pranikah bagi calon pengantin;

(6) Calon pengantin yang mengikuti bimbingan perkawinan pranikah bagi calon pengantin mendapat buku fondasi keluarga sakinah: bacaan mandiri calon pengantin yang diterbitkan oleh Kementerian Agama;

\footnotetext{
${ }^{14}$ Ibid.
} 
(7) Calon pengantin dapat melakukan bimbingan perkawinan secara perorangan, berpasangan, atau berkelompok;

(8) Pelaksanaan bimbingan perkawinan pranikah bagi calon pengantin berupa: bimbingan tatap muka atau bimbingan mandiri. ${ }^{15}$

Kegiatan bimbingan perkawinan pranikah dilaksanakan di Kantor Kementerian Agama Kota Makassar di bawah koordinator teknis penyelenggaraan bimbingan perkawinan pranikah bagi calon pengantin adalah Kepala Seksi Bimbingan Masyarakat Islam pada Kantor Kementerian Agama Kota Makassar.

Demikian halnya dengan peserta bimbingan perkawinan pranikah, selain calon pengantin juga dapat diberikan kepada remaja yang telah memasuki usia nikah di wilayah Kecamatan Ujung Tanah Kota Makassar. Kegiatan bimbingan perkawinan pranikah bagi remaja usia nikah sudah berlangsung sejak tiga tahun terakhir, yaitu tahun 2017 mendapatkan jatah 2 angkatan, pada tahun 2018 mendapat jatah 4 angkatan dan pada tahun 2019 juga mendapatkan jatah 4 angkatan yang pesertanya masing-masing utusan dari Kecamatan se-Kota Makassar dan siswa MA/SMA.

b. Bimbingan Tatap Muka

Tahap bimbingan tatap muka, yaitu:

(1) Bimbingan tatap muka dilaksanakan selama 16 jam pelajaran, sesuai dengan modul yang diterbitkan Kementrian Agama;

(2) Materi Bimbingan Perkawinan Pranikah Bagi Calon Pengantin:

(a) Paparan kebijakan bimbingan perkawinan sebanyak 2 jam pelajaran;

(b) Perkenalan, pengutaraan harapan dan kontrak belajar sebanyak 1 jam pelajaran;

(c) Mempersiapkan keluarga sakinah sebanyak 2 jam pelajaran;

(d) Membangun hubungan dalam keluarga sebanyak 3 jam pelajaran;

(e) Memenuhi kebutuhan keluarga sebanyak 2 jam pelajaran;

(f) Menjaga kesehatan reproduksi sebanyak 2 jam pelajaran;

(g) Memepersiapkan generasi berkualitas sebanyak 2 jam pelajaran;

(h) Refleksi, evaluasi dan post test sebanyak 2 jam pelajaran.

\footnotetext{
${ }^{15}$ Ibid.
} 
(3) Narasumber bimbingan perkawinan pranikah bagi calon pengantin:

(a) Seluruh proses bimbingan perkawinan (16 jam pelajaran) wajib diampu oleh minimal 2 orang narasumber terbimtek (fasilitator) yang telah mengikuti dan mendapatkan sertifikat bimbingan teknis fasilitator bimbingan perkawinan pranikah bagi calon pengantin yang diselesnggrakan oleh Kementrian Agama atau lembaga lain yang telah mendapatkan izin Kementrian Agama;

(b) Dalam hal diperlukan, untuk materi pada angka huruf a dapat disampaikan oleh narasumber dari unsur Kantor Wilayah Kementrian Agama Provinsi atau Kantor Kementrian Agama Kabupaten atau Kota;

(c) Materi pada angka 2 huruf f dapat disampaikan oleh narasumber dari unsur puskesmas.

(4) Bimbingan tatap muka sebagaimana dimaksud pada angka 1 dilaksanakan selama 2 hari berturut turut atau selang satu hari, dan bilamana diperlukan dapat memanfaatkan hari sabtu dan atau minggu;

(5) Materi pre tes dilakukan sewaktu peserta bimbingan calon pengantin melakukan registrasi;

(6) Bimbingan Perkawinan Pranikah Bagi Calon Pengantin dilaksanakan sesuai waktu yang telah ditentukan pihak penyelenggra sebelum pelaksanaan nikah;

(7) Tempat pelaksanaan

(a) Bimbingan perkawinan pranikah bagi calon pengantin dapat dilaksanakan di Kantor Urusan Agama Kecamatan, Kantor Kementerian Agama Kabupaten Atau Kota, atau tempat lain yang di tetapkan oleh penyelenggara;

(b) Pelaksanaan bimbingan perkawinan pranikah bagi calon pengantin disesuaikan dengan kondisi wilayah masing-masing.

(8) Dalam hal peserta Bimbingan Perkawinan Pranikah Bagi Calon Pengantin kurang dari 50 orang atau 25 pasang, pelaksanaannya dapat digabung dengan beberapa kecamatan dan dikoordinasikan oleh Kepala Seksi Bimas Islam Kab/Kota setempat.

c. Bimbingan Mandiri

Mekanisme pelaksanaan bimbingan mandiri sebagai berikut: 
(1) Dalam hal calon pengantin tidak dapat mengikuti bimbingan tatap muka, calon pengantin dapat mengikuti bimbingan mandiri;

(2) Bimbingan mandiri hanya dilaksanakan pada KUA tipologi D1 dan D2;

(3) Bimbingan mandiri dilaksanakan dengan memenuhi ketentuan sebagai berikut:

(a) Peserta bimbingan mendapat buku bacaan mandiri yang diterbitkan oleh Kementerian Agama;

(b) Pada saat mendaftar kehendak nikah di KUA Kecamatan, calon pengantin mendapat bimbingan perkawinan pra nikah tentang dasar dasar perkawinan, membangun keluarga sakinah, dan peraturan perundangan yang berhubungan dengan masalah keluarga;

(c) Calon pengantin mendatangi puskesmas untuk mendapat bimbingan kesehatan reproduksi, pola hidup bersih dan sehat, dan kesehatan keluarga, dibuktikan dengan surat keterangan bimbingan kesehatan keluarga dari puskesmas;

(d) Selain memenuhi ketentuan sebagaimana dimaksud huruf a, b, dan c, calon pengantin mendapatkan penasehatan dan bimbingan dari 2 orang penasehat, dari unsur konselor BP4, penghulu, penyuluh agama islam, ulama, psikolog, atau praktisi pendidikan di wilayah tempat tinggal atau di wilayah yang dapat dijangkau oleh calon pengantin mengenai: a. Membangun hubungan dalam keluarga dan memenuhi kebutuhan keluarga sebanyak 2 jam b. Mempersiapkan generasi berkualitas sebanyak 2 jam. Hal tersebut dibuktikan dengan surat pernyataan penasehatan yang ditandatangani oleh penasehat;

(e) Blanko surat pernyataan penasehatan sebagaimana dimaksud pada huruf $d$ disediakan oleh KUA sebagaimana format terlampir.

Terkait dengan bimbingan perkawinan pranikah yang dilaksanakan secara mandiri di Kecamatan Ujung Tanah hanya dilakukan pada KUA tipologi D1 dan D2, yang secara kebetulan KUA Kecamatan Ujung Tanah masuk pada tipologi D2 karena memiliki wilayah kepulauan yaitu Pulau Barrang Lompo, Pulau Barrang Caddi dan Pulau Kodingareng. Semua calon pengantin yang berasal dari ke 3 pulau ini mendapatkan bimbingan perkawinan pranikah secara mandiri di Kantor Urusan Agama Kecamatan Ujung Tanah Kota Makassar. 


\section{d. Sertifikat}

Tahap selanjutnya dalam pelaksanaan bimbingan perkawinan pra nikah, yaitu:

(1) Peserta yang telah mengikuti bimbingan perkawinan pra nikah bagi calon pengantin berhak memperoleh sertifikat dari penyelenggara;

(2) Sertifikat diterbitkan dan ditandatangani oleh penyelenggara;

(3) Bagi peserta bimbingan mandiri, surat keterangan bimbingan kesehatan keluarga dan pernyataan penasehatan menjadi pengganti sertifikat.

Oleh karena itu bagi peserta bimbingan perkawinan pranikah yang dilaksanakan secara tatap muka di Kementerian Agama Kota Makassar, akan diberikan sertifikat sebagai bukti telah mengikuti bimbingan perkawinan pranikah, sementara bagi peserta bimbingan perkawinan pranikah yang dilaksanakan secara mandiri tidak diterbitkan sertifikat melainkan surat keterangan bimbingan kesehatan keluarga dan surat pernyataan penasihatan sebagai pengganti sertifikat.

Sertifikat tersebut akan menjadi syarat kelengkapan administrasi perkawinan, sekalipun dokumen itu bersifat tidak wajib tetapi sanggat dianjurkan memilikinya, karena dengan mendapatkan sertifikat berarti pasangan telah memiliki bekal pengetahuan dan keterampilan tentang membangun rumah tangga dan berupaya mempersiapkan diri secara matang untuk mengarungi kehidupan baru, yaitu dengan membekali dirinya pengetahuan dan pemahaman tentang seluk beluk berumah tangga sehingga apapaun tantangan yang mereka hadapi nantinya akan diantisipasi secara baik karena sudah mendapatkan bekal.

\section{Maksud dan Tujuan Bimbingan Perkawinan Pranikah}

Maksud dilaksanakannya bimbingan perkawinan pranikah adalah sebagai wujud nyata kesungguhan Kementerian Agama dalam memastikan pembangunan bangsa melalui keharmonisan perkawinan yang ideal, mencakup penyediaan sumber daya manusia. ${ }^{16}$ Artinya dengan diadakannya bimbingan perkawinan pranikah ini diharapkan dapat mengantisipasi terjadinya perselisihan dan perceraian maupun kekerasan dalam keluarga agar tercipta keluarga sakinah, mawaddah, dan rahmah.

\section{${ }^{16}$ Ibid.}


Menurut Badaruddin sebagaimana yang dikutip oleh Ari Azhari, ada dua tujuan yang ingin dicapai dari penyelenggaraan bimbingan perkawinan pranikah ini, memiliki tujuan umum dan tujuan khusus. Adapun tujuan umum yang dimaksud adalah untuk mewujudkan keluarga sakinah, mawaddah, dan warahmah melalui pemberian bekal pengetahuan, peningkatan pemahaman dan keterampilan tentang kehidupan rumah tangga dan keluarga. Sedangkan tujuan khusus yang ingin dicapai adalah untuk menyamakan persepsi badan/lembaga dan terwujudnya bimbingan perkawinan pranikah bagi remaja usia nikah dan calon pengantin. ${ }^{17}$

Dengan demikian dapat dipahami bahwa maksud dan tujuan pelaksanaan bimbingan perkawinan pranikah adalah untuk menciptakan masyarakat Indonesia menjadi insan yang berkualitas dalam membina kehidupan rumah tangga yang harmonis serta mampu menghadapi tantangan global yang semakin berat.

Sementara dalam Peraturan Direktur Jenderal Bimbingan Masyarakat Islam Departemen Agama No. DJ. II/491 Tahun 2009 tentang Kursus Calon Pengantin, disebutkan bahwa tujuan diadakannya bimbingan perkawinan sebagai berikut:

a. Untuk memberikan bekal bagi remaja usia nikah, calon suami istri menuju mahligai rumah tangga;

b. Untuk memantapkan lembaga rumah tangga yang kokoh dan lestari menuju terwujudnya keluarga sakinah;

c. Untuk mengurangi angka perselisihan, penceraian dan kekerasan dalam rumah tangga. $^{18}$

Dengan demikian bimbingan perkawinan pranikah memiliki beberapa manfaat kepada pasangan suami-istri diantaranya yaitu masa depan lebih terarah, mengurangi resiko keretakan hubungan, memudahkan dalam penyatuan visi dan saling memahami keluarga pasangan. Bimbingan perkawinan pranikah sangatlah penting sebagai wahana membimbing dua orang yang berbeda untuk saling berkomunikasi, belajar menyelesaikan masalah dan mengelola konflik. Keterampilan ini sangat penting dalam

\footnotetext{
${ }^{17}$ Ari Azhari, "Pelaksanaan Kursus Pra-Nikah (Studi Komperatif di Kantor Urusan Agama Kec. Gondukusuma Kota Yogyakarta dengan Lembaga Pembinaan Persiapan Hidup Berkeluarga Kevikepan DIY)," Tesis (Yogyakarta: Prodi Hukum Islam Konsentrasi Hukum Keluarga, 2014), 25-26.

${ }^{18}$ Kementerian Agama RI., Peraturan Direktur Jenderal Bimbingan Masyarakat Islam Departemen Agama No. DJ. II/491 Tahun 2009 tentang Kursus Calon Pengantin, Pasal 2.
} 
perjalanan kehidupan rumah tangga seseorang. Pasangan muda sangat membutuhkan bimbingan terutama untuk memperjelas harapan- harapan mereka pada pernikahannya dan memperkuat hubungan sebelum menikah. Peranan bimbingan perkawinan pranikah sangat terkait dengan tujuan pernikahan, yaitu dalam hal mewujudkan keluarga yang sakinah sesuai dengan tunt unan agama Islam.

3. Unsur-Unsur Bimbingan Perkawinan Pranikah

a. Fasilitator/Narasumber Bimbingan Perkawinan Pranikah

Pada dasarnya seluruh proses bimbingan perkawinan pranikah wajib diampu oleh minimal 2 orang narasumber terbimtek (fasilitator) yang telah mengikuti dan mendapatkan sertifikat bimbingan teknis fasilitator bimbingan perkawinan pranikah bagi calon pengantin yang diselesnggrakan oleh Kementrian Agama atau lembaga lain yang telah mendapatkan izin Kementrian Agama. ${ }^{19}$

Fasilitator yang pernah mengikuti bimbingan teknis dan mendapatkan sertifikat sebagai fasilitator/narasumber sebanyak 7 orang yang berasal dari Kementerian Agama Kota Makassar, yaitu:

(1) H. Ambo Sakka Ambo, M.Ag. (Kepala Seksi Bimas Islam)

(2) Dr. H. Saifullah Rusmin, M.Ag. (Penyuluh Agama Islam)

(3) Dr. Syamsu Alam Usman, M.Ag. (Penghulu Madya/Kepala KUA)

(4) Ahmad Jazil, S.Th.I, M.Pd. (Penghulu Madya/Kepala KUA)

(5) Nurdin, S.Ag, MH. (Penyuluh Agama Islam/Ketua Pokjaluh)

(6) Syamsiah, S.Ag, M.Si. (Penyuluh Agama Islam)

(7) Hasnah, S.Pd, S.Hi. (Penyuluh Agama Islam). ${ }^{20}$

b. Peserta Bimbingan Perkawinan Pranikah

Subjek bimbingan pranikah ada dua yaitu calon pengantin yang telah mendaftar di Kantor Urusan Agama Kecamatan, dan remaja yang telah memasuki usia 21 (dua puluh satu) tahun. ${ }^{21}$ Dengan demikian yang akan menjadi peserta bimbingan

\footnotetext{
${ }^{19}$ Kementerian Agama RI., Keputusan Direktur Jenderal Bimbingan Masyarakat Islam Nomor 379 Tahun 2018 tentang Petunjuk Pelaksanaan Bimbingan Pranikah Bagi Calon Pengantin.

${ }^{20}$ Sumber Data Seksi Bimas Islam Kementerian Agama Kota Makassar Tahun 2020.

${ }^{21}$ Kementerian Agama RI., Keputusan Direktur Jenderal Bimbingan Masyarakat Islam Nomor 379 Tahun 2018 tentang Petunjuk Pelaksanaan Bimbingan Pranikah Bagi Calon Pengantin.
} 
perkawinan pranikah adalah calon pengantin yang menjadi prioritas yang telah mendaftarkan diri di Kantor Urusan Agama Kecamatan dengan memanfaatkan 10 hari kerja sebelum pelaksanaan pernikahan, di mana calon pengantin dengan jumlah peserta perangkatannya sebanyak 25 pasang yang berasal dari utusan seluruh KUA Kecamatan yang ada di Kota Makassar yang sebelumnya diberikan kouta masing-masing KUA Kecamatan.

Peserta yang akan mengikuti bimbingan perkawinan pranikah di wilayah Kecamatan Ujung Tanah adalah calon pengantin yang telah mendaftarkan diri di Kantor Urusan Agama Kecamatan dan dinyatakan memenuhi segala syarat dan kelengkapan berkas administrasi nikah. Lain halnya dengan peserta bimbingan perkawinan pranikah yang kategori usia remaja. Syaratnya untuk mengikuti bimbingan perkawinan pranikah tidaklah seperti calon pengantin, namun yang menjadi syarat adalah remaja putra dan putri yang sudah memasuki usia nikah.

c. Materi Bimbingan Perkawinan pranikah

Bimbingan perkawinan pranikah yang dilaksanakan oleh Kementerian Agama Kabupaten/Kota kepada para calon pengantin, pelaksanaannya sebelum akad nikah dilaksanakan selama 16 JPL (Jam Pelajaran) atau selama dua hari. Adapun materi bimbingan perkawinan pranikah yang disampaikan oleh fasilitator/narasumber yaitu :
a. Paparan kebijakan bimbingan perkawinan sebanyak 2 jam pelajaran;
b. Perkenalan, pengutaraan harapan dan kontrak belajar sebanyak 1 jam pelajaran;
c. Mempersiapkan keluarga sakinah sebanyak 2 jam pelajaran;
d. Membangun hubungan dalam keluarga sebanyak 3 jam pelajaran;
e. Memenuhi kebutuhan keluarga sebanyak 2 jam pelajaran;
f. Menjaga kesehatan reproduksi sebanyak 2 jam pelajaran;
g. Mempersiapkan generasi berkualitas sebanyak 2 jam pelajaran; dan
h. Refleksi, evaluasi dan post test sebanyak 2 jam pelajaran. ${ }^{22}$

Dengan demikian ada delapan materi bimbingan perkawinan pranikah yang harus terpenuhi dalam pelaksanaan bimbingan perkawinan pranikah. Sedangkan modul yang digunakan adalah buku Modul bimbingan perkawinan pranikah untuk calon

\footnotetext{
${ }^{22}$ Ibid.
} 
pengantin dan buku Fondasi Keluarga Sakinah: Bacaan Mandiri Calon Pengantin yang diterbitkan oleh Kementerian Agama Tahun 2018.

Topik utama modul ini terdiri dari 6 materi pokok, yaitu: (1) mempersiapkan keluarga sakinah, (2) membangun hubungan dalam keluarga, (3) memenuhi kebutuhan keluarga, (4) menjaga kesehatan reproduksi, (5) mempersiapkan generasi erkualitas, dan (6) mengelola konflik dan membangun ketahanan keluarga. Enam materi pokok ini dilengkapi dengan dua materi penunjang yaitu perkenalan, harapan dan kekhawatiran, kontrak belajar, di awal proses dan refleksi dan evaluasi di akhir proses. ${ }^{23}$ Dengan demikian secara keseluruhan ada 8 materi dalam bimbingan perkawinan pranikah, diantaranya ada 6 yang merupakan materi pokok/inti sementara 2 materi lainnya merupakan materi tambahan dengan durasi waktu 16 jam secara keseluruhan selama 2 hari pelaksanaan.

Modul yang digunakan ada dua yakni modul 1 dan modul 2 yang masingmasing modul memiliki 4 sesi. Modul pertama, fokus pada empat sesi yaitu: (1) Perkenalan dan kontrak belajar, (2) Mempersiapkan perkawinan kokoh menuju keluarga sakinah, (3) Mengelola dinamika perkawinan dan keluarga, dan (4) Memenuhi kebutuhan keluarga. Sedangkan pada Modul kedua, focus pada empat sesi yaitu: (1) Menjaga kesehatan reproduksi keluarga, (2) Menyiapkan generasi berkualitas, (3) Mengelola konflik dan membangun ketahanan keluarga, dan (4) Refleksi dan evaluasi.

Pada modul kesatu sesi pertama adalah perkenalan dan kontrak belajar, yang pokok pembahasannya terdiri dari: pengutaraan harapan,kekhawatiran dan aturan main. Materi ini menjadi pembuka seluruh rangkaian kegiatan bimbingan, dengan tujuan untuk menciptakan keakraban, komunikatif, dialogis dan partisipatoris. Materi ini menitik beratkan pada pengenalan, terhadap sesama peserta dan juga memperkenalkan seluruh materi yang akan disampaikan, identifikasi harapan dan kekhawatiran, kesepakatan jadwal bimbingan, dan kontrak belajar. ${ }^{24}$ Metode yang digunakan pada sesi ini adalah game angin bertiup, curah pendapat, diskusi kelompok dan presentasi.

\footnotetext{
${ }^{23}$ Kementerian Agama RI., Modul Bimbingan Perkawinan (Cet. 1; Jakarta: Subdit Bina Keluarga Sakinah Direktorat Bina KUA dan Keluarga Sakinah Ditjen Bimas Islam Kemenag RI, 2017)

${ }^{24}$ Ibid.
} 
Sesi kedua, mempersiapkan perkawinan kokoh menuju keluarga sakinah. Pokok pembahasan dalam materi ini adalah status sebagai hamba Allah dan amanah sebagai khalifah di bumi, Keluarga Sakinah dan Perkawinan yang terencana. ${ }^{25}$ Status yang melekat pada setiap manusia sebagai hamba Allah dan amanah sebagai Khalifah di muka bumi termasuk dalam kehidupan perkawinan dan keluarga. Perkawinan dan keluarga mesti mempunyai tujuan yang sejalan dengan citacita jangka panjang ketika menghadap Ilahi di Akhirat kelak, dan dikelola sesuai dengan status dan amanah yang melekat pada manusia. Dengan tujuan peserta mampu merumuskan cita-cita tertinggi hidup, mengaitkannya dengan tujuan jangka panjang dan pendek perkawinan, serta mewujudkannya selaras dengan status sebagai hamba Allah dan khalifah di muka bumi. Metode yang digunakan adalah sungai kehidupan, curah pendapat, ceramah/tanya jawab, diskusi kelompok dan presentasi.

Sesi ketiga, mengelola dinamika perkawinan dan keluarga. Pokok pembahasan dalam materi ini adalah Komponen hubungan perkawinan dan tahap perkembangan hubungan, penghancur dan pembangun hubungan, kesiapan menikah serta ketermpilan komunikasi. ${ }^{26}$ Materi ini mengajak peserta mengeksplorasi ciri kehidupan perkawinan yang sukses dan yang gagal, sehingga dapat menyimpulkan tantangan dalam kehidupan berkeluarga. Setelah itu, peserta akan belajar komponen penting dalam hubungan pasangan, dan tahap perkembangan hubungan pasangan suami istri, penghancur hubungan dan pembangun hubungan, serta hal-hal penting untuk membangun perkawinan yang baik. Tujuan materi ini adalah peserta mengenali hal-hal terpenting di dalam perkawinan bagi dirinya dan bagi pasangannya, peserta memiliki kesadaran diri dan kesadaran sosial yang terkait dengan dinamika perkawinan, peserta memahami perspektif Islam tentang dinamika hubungan keluarga, komponen hubungan perkawinan, tahap perkembangan hubungan dalam perkawinan, sikap penghancur hubungan, dan sikap pembangun hubungan. Metode yang digunakan adalah game, tuas kelompok, tugas pasangan, bermain peran, presentasi, ceramah dan tanya jawab.

Sesi keempat, memenuhi kebutuhan keluarga. Pokok pembahasan dalam materi ini adalah konsep pemenuhan kebutuhan keluarga sebagai ibadah, kebutuhan fisik dan

\section{${ }^{25}$ Ibid. \\ ${ }^{26} \mathrm{Ibid}$.}


non fisik dalam keluarga dan strategi team kerja dalam pemenuhan kebutuhan keluarga. $^{27}$ Sesi ini mengajak peserta untuk mengidentifikasi dan mengenal jenis-jenis kebutuhan dalam membangun keluarga yang sakinah, mawaddah dan rohmah. Tujuan materi ini adalah peserta mampu mengidentifikasi jenis jenis kebutuhan keluarga, peserta mampu memahami peran dan tugas yang harus dibagi dalam upaya pemenuhan kebutuhan keluarga, peserta memiliki beberapa langkah alternatif dalam pemenuhan kebutuhan keluarga yang direfleksikan dengan situasi terkini yang keduanya miliki saat ini, peserta memahami dalam pemenuhan kebutuhan keluarga diperlukan bekerjasama suami istri sebagai satu team work (tim kerja) dengan visi misi yang dipahami bersama. Metode yang digunakan adalah curah pendapat, asupan narasumber, refleksi diri dan menyusun rancangan pemenuhan kebutuhan keluarga.

Di samping empat sesi pada modul pertama di atas akan dibahas modul kedua yang terdiri dari empat sesi, sesi pertama adalah materi menjaga kesehatan reproduksi keluarga, Pokok pembahasan dalam materi ini adalah perbedaan organ, fungsi, masa dan dampak reproduksi pada laki-laki dan perempuan, hak dan kewajiban reproduksi laki-laki dan perempuan, keluarga berencana dan tuntunan Islam terkait masa reproduksi dan Keluarga Berencana. ${ }^{28}$ Kesehatan reproduksi adalah merupakan salah satu pilar keluarga sakinah ynag memiliki peran dalam mencapai kebahagiaan Apabila terganggu, maka kehidupan keluarga dapat mengalami masalah, bahkan jika sampai terjadi kematian maka bangunan keluarga terancam koyak. Oleh karenanya, sejak dini para calon pengantin perlu dibekali pengetahuan tentang kesehatan reproduksi keluarga, dan relasi hubungan seksual dalam Islam sehingga setara dan bermartabat. Dengan demikian, calon pengantin sama-sama memahami bahwa tanggung jawab kesehatan reproduksi keluarga merupakan tanggung jawab bersama. Materi ini bertujuan agar peserta mampu memahami konsep Kesehatan reproduksi keluarga dan peserta memiliki keterampilan untuk mendiskusikan hal-hal terkait kesehatan reproduksi secara terbuka dengan calon suami/ istrinya. Metode yang digunakan adalah curah pendapat, ceramah dan tanya jawab, diskusi berpasangan, diskusi kelompok, presentasi dan bermain bola.

\section{${ }^{27}$ Ibid. \\ ${ }^{28}$ Ibid.}


Materi pada sesi kedua, menyiapkan generasi berkualitas. Pokok pembahasan dalam materi ini adalah konsep anak saleh dan salehah, peran, tugas dan tanggungjawab orangtua, pola pengasuhan anak dan kesepakatan kami kompak. ${ }^{29}$ Materi ini mengajak peserta mengeksplorasi pemikiran dan harapan mereka tentang anak-anak dalam keluarga mereka, dan menyelaraskannya dengan konsep dan prinsip perkembangan anak secara Islami. Peserta mengeksplorasi mengenai peran, tugas, dan kewajiban orangtua, juga tantangan dan kesalahpahaman umum. Pada bagian terakhir, peserta membuat kesepakatan Kami Kompak dengan pasangan mengenai hal-hal yang mereka harapkan dan akan mereka terapkan dalam pengasuhan anak nantinya. Tujuan materi ini adalah peserta memahami prinsip perkembangan anak dan pola pengasuhan anak dalam Islam, peserta memiliki kesadaran diri atas perannya sebagai orangtua, peserta memiliki kesepakatan dengan pasangan mengenai prinsip pengasuhan anak yang akan diterapkan dalam keluarga. Metode yang digunakan adalah game, tugas kelompok, presentasi, tugas pasangan, bermain peran, ceramah dan tanya jawab.

Sesi ketiga, mengelola konflik dan membangun ketahanan keluarga. Pokok pembahasan dalam materi ini adalah sumber konflik dan ancaman ketahanan keluarga, cara mengelola konflik dan membangun ketahanan keluarga. ${ }^{30}$ Materi ini menguatkan pengetahuan peserta tentang tantangan yang semakin kompleks, baik di dalam maupun di luar keluarga. Sesi ini juga melatih bagaimana pasangan suami-istri bisa mengelola perbedaan secara dinamis, membangun kesepakatan bersama dalam menghadapinya, dan mengenalkan bagaimana cara merespon tantangan-tantangan tersebut, terutama dengan menumbuhkan karakter diri yang tangguh, bertanggung-jawab, mawas diri, demokratis, dan fleksibel. Pada materi ini, bertujuan agar peserta mengenali sumbersumber konflik dan bagaimana mengelolanya dalam kehidupan rumah tangga yang dinamis, peserta mengenali dan mampu mengantisipasi tantangan di dalam dan di luar keluarga yang mengancam ketahanan keluarga, peserta dapat membentengi diri dari berbagai kemungkinan yang dapat meruntuhkan keutuhan keluarga. Metode yang digunakan adalah studi kasus, diskusi kelompok, presentasi, ceramah dan tanya jawab.

\section{${ }^{29}$ Ibid. \\ ${ }^{30}$ Ibid.}


Pada sesi ini peserta dibagi menjadi dua bagian. Kelompok satu akan berdiskusi tentang cara mengelola konflik dan membangun ketahanan keluarga berdasarkan kasus yang berbeda. Kelompok kedua akan mendiskusikan fakta-fakta dalam kasus serta menganalisisnya. Masing-masing kelompok mempresentasikan hasil diskusi yang akan ditanggapi oleh kelompok lain dan juga narasumber.

Sesi keempat, merupakan sesi terakhir yaitu refleksi dan evaluasi. Pokok pembahasan dalam materi ini adalah refleksi diri dan pasangan dan evaluasi proses bimbingan. ${ }^{31}$ Dalam sesi ini, peserta diajak melakukan refleksi tentang dampak dari proses bimbingan perkawinan pada persiapan mental mereka menuju perkawinan. Selain itu, peserta juga diajak melakukan evaluasi terhadap proses bimbingan, baik secara substansi maupun teknis agar bisa dijadikan dasar peningkatan layanan bimbingan perkawinan selanjutnya. Metode yang digunakan adalah menggambar, curah pendapat, mengisi kuesioner dan mengisi angket.

Materi dari modul pertama sampai pada modul kedua yang menjadi narasumber/pengampuh adalah para fasilitator yang telah mendapatkan pelatihan serta bersertifikat. Namun materi tentang menjaga kesehatan reproduksi bisa diampuh dari Dinas Kesehatan/BKKBN. Intinya bahwa materi yang didapatkan para peserta dalam bimbingan perkawinan pranikah ini diantaranya adalah materi yang berkaitan dengan kehidupan berumah tangga, manajemen keluarga, komunikasi, keuangan, kesehatan reproduksi, konflik dalam rumah tangga serta do'a-do'a berhubungan.

\section{d. Metode}

Metode pembelajaran adalah cara atau teknik penyajian materi yang akan digunakan oleh fasilitator/narasumber pada saat menyajikan, baik secara individual atau secara kelompok, agar tercapai tujuan pembelajaran yang telah dirumuskan, haruslah mengetahui berbagai metode dalam menyampaikan materi, dengan memiliki pengetahuan berbagai metode maka fasilitator akan lebih mudah menerapkan metode yang paling tepat dan sesuai dengan situasi dan kondisi. ${ }^{32}$ Proses penyampaian materi bimbingan perkawinan pranikah agar memudahkan dan cepat dipahami bagi peserta

\footnotetext{
${ }^{31}$ Ibid.

${ }^{32}$ Ahmad Sabri, Strategi Belajar Mengajar dan Micro Teaching (Cet. 2; Ciputat: PT Ciputat Press, 2007), 49.
} 
bimbingan perkawinan pranikah maka dibutuhkan berbagai metode sebagai pendukung proses terlaksanakannya bimbingan perkawinan pranikah bagi calon pengantin.

Berdasarkan dalam modul bimbingan perkawinan untuk calon pengantin ada beberapa metode yang dapat dipakai dalam menyampaikan sebuah materi diantaranya adalah: (1) metode curah pendapat, (2) metode diskusi kelompok, (3) presentasi, (4) ceramah dan tanya jawab, (5) game, (6) tugas kelompok, (7) tugas pasangan, (8) roleplay (bermain peran), (9) asupan narasumber, (10) refleksi diri, dan (11) studi kasus. ${ }^{33}$

Selain beberapa metode yang digunakan juga menerapkan model pembelajaran orang dewasa (andragogi). Model pembelajaran orang dewasa adalah menempatkan peserta sebagai orang yang sudah mempunyai pengetahuan, pengalaman, dan keterampilan sehingga dapat mengarahkan diri sendiri.

Dengan model ini, maka seluruh peserta bimbingan perkawinan pranikah diposisikan sebagai narasumber yang sudah memiliki pengetahuan, keterampilan dan pengalaman. Oleh karenanya, proses bimbingan bersifat partisipatoris yang melibatkan peserta sebagai subyek aktif melalui berbagai macam kegiatan dalam bentuk curah pendapat, diskusi kelompok, diskusi berdua dengan calon pasangan, tanya-jawab, bermain peran, maupun yang lainnya.

e. Media

Media adalah segala sesuatu yang dapat digunakan untuk menyalurkan pesan dari pengirim ke penerima. Sehingga dapat merangsang pikiran, perasaan, perhatian dan minat peserta. ${ }^{34}$ Media adalah sarana yang dapat digunakan untuk menyampaikan sesuatu kepada orang lain agar dapat mudah menerima apa yang disampaikan.

Salah satu unsur penunjang dalam pembelajaran adalah didukung dengan media/sarana dan prasarana yang tersedia, sehebat apapun materi dan metode yang digunakan lika tidak didukung dengan media maka tidak sempurna dalam menyampaikan materi tersebut.

Sebagaimana yang disebutkan dalam modul bimbingan perkawinan untuk calon pengantin bahwa ada beberapa media yang dapat digunakan dalam bimbingan

\footnotetext{
${ }^{33}$ Sumber data Modul Bimbingan Perkawinan untuk Calon Pengantin.

${ }^{34}$ Azhar Arsyad, Media Pembelajaran (Jakarta: Raja Grafindo Persada, 2003), 3.
} 
perkawinan pranikah ini diantaranya adalah : (1) instrument pre - test, (2) kertas flipchart, (3) kertas metaplan, (4) Spidol besar/kecil, (5) Lakban, (6) kertas HVS, (7) LCD, (8) Laptop, (9) papan tulis putih, (10) alat tulis, (11) gambar, (12) pulpen/pensil, (13) buku/modul, (14) instrument post - test dan (15) instrument evaluasi. ${ }^{35}$

Peran bimbingan perkawinan pranikah dalam menciptakan keluarga sakinah di wilayah Kecamatan Ujung Tanah Kota Makassar bahwa salah satu tujuan perkawinan adalah membentuk keluarga yang sakinah mawaddah warahmah. Tujuan tersebut tentu menjadi cita-cita dan harapan bagi setiap pasangan suami-istri sebagaimana diterangkan dalam QS. al-Rum/30: 21.

Untuk mewujudkan keluarga sakinah tentu memerlukan pengetahuan dan keterampilan yang cukup bagi pasangan suami-istri sebelum melangsungkan pernikahannya, bahkan sejak dini perlu ada pembekalan. Karena dalam mengarungi perjalanan berumah tangga, mereka pasti akan menghadapi pelbagai persoalan dan konflik keluarga, namun dinamika kehidupan keluarga itu bisa dikelola dengan baik sehingga para pasangan suami-istri semakin memperkokoh fondasi keluarga sakinah.

Untuk mewujudkan keluarga sakinah perlu adanya upaya kongkrit dari pemerintah dalam hal bimbingan perkawinan, dengan harapan bahwa dengan adanya bimbingan perkawinan keluarga sakinah akan tercapai, karena salah satu indikasi banyaknya perceraian diakibatkan ketidaktahuan peran dari masing-masing pihak. Sebagai wujud perhatian pemerintah melalui Kementerian Agama sudah mengambil langkah preventif dengan membuat terobosan yakni melalui kegiatan bimbingan perkawinan pranikah yang sudah berjalan sejak tahun 2009 yang lalu, namun seiring dengan perjalanan waktu kegiatan ini sudah mengalami perubahan nama, sampai pada tahun 2018 setelah diterbitkannya Keputusan Direktur Jenderal Bimbingan Masyarakat Islam Nomor 379 Tahun 2018 tentang Petunjuk Pelaksanaan Bimbingan Perkawinan Pranikah Bagi Calon Pengantin.

Kegiatan bimbingan perkawinan pranikah ini merupakan prioritas nasional yang dipantau langsung oleh Presiden. Untuk mendukung kegiatan tersebut Kementerian Agama RI mengeluarkan anggaran yang berasal dari PNBP NR. Bahkan

\footnotetext{
${ }^{35}$ Sumber Data Modul Bimbingan Perkawinan Untuk Calon Pengantin.
} 
bukan hanya program bimbingan perkawinan pranikah yang dilaksanakan oleh Kementerian Agama, akan tetapi juga memiliki program unggulan yakni Pusat Layanan Keluarga Sakinah (Pusaka Sakinah), pusaka sakinah diadakan dalam rangka mendukung rencana pemerintah dibidang pembangunan dan ketahanan keluarga untuk mewujudkan keluarga sakinah. Program pusaka sakinah adalah wujud nyata kesungguhan Kementerian Agama dalam memastikan keharmonisan perkawinan yang ideal. Pusaka sakinah ini merupakan kelanjutan dari program bimbingan perkawinan pranikah, yang dilaksanakan pasca pernikahan diperuntukkan kepada pasangan yang sudah menikah yakni usia di bawah 40 tahun dan usia pernikahan di bawah 10 tahun.

\section{Kendala dalam Pelaksanaan Bimbingan Perkawinan Pranikah di Kecamatan Ujung Tanah Kota Makassar}

Gagasan menentukan harapan sedangkan kejiwaan memberikan daya yang akan menghasilkan tindakan. Kesiapan jiwa mampu menumbuhkan keinginan, obsesi, kuriositas, dan rasa optimis. Selain itu juga bisa melahirkan efikasi diri, yaitu keyakinan yang kuat untuk sukses dan berhasil. ${ }^{36}$ Namun untuk mencapai sebuah kesuksesan tidak lepas dari kendala yang dihadapi. Hal yang sama terjadi pada pelaksanaan bimbingan perkawinan pranikah di wilayah Kecamatan Ujung Tanah dengan kendala-kendala yang dihadapi sebagai berikut:

1. Kendala Bimbingan Perkawinan Pranikah Terhadap Fasilitator

Kendala bagi fasilitator dalam memberikan materi adalah media yang kurang mendukung ditandai dengan LCD/Proyektor yang tidak berfungsi bahkan sama sekali tidak menggunakan alat tersebut dalam menyampaikan materi, berdasarkan penelusuran bahwa pada awal pelaksanaan bimbingan perkawinan pranikah alat tersebut berfungsi dengan baik, namun karena seringnya digunakan sehingga mengalami kerusakan dan belum ada upaya untuk memperbaiki. Diketahui bahwa LCD/Proyektor merupakan salah satu media dalam mendukung menyampaikan materi kepada peserta agar mudah dipahami dan dimengerti. Sehingga dengan demikian harus ada upaya tindak lanjut untuk memperbaiki agar para fasilitator dapat menyajikan materinya dengan baik dan tepat.

\footnotetext{
${ }^{36}$ Dwi Budiyanto, Prophetic Learning (Yogyakarta:Pro-U Media, 2012), 61.
} 
Kendala yang kedua dalam pelaksanaan bimbingan perkawinan pranikah adalah belum adanya keharusan kepada seluruh calon pengantin untuk mengikuti bimbingan perkawinan pranikah, hal ini tentu menjadi problem ketika fasilitator memberikan materinya kurang peserta yang hadir. hal ini disebabkan karena kouta sudah ditetapkan oleh Kementerian Agama Pusat, berdasarkan data yang diperoleh dari Seksi Bimas Islam bahwa jumlah peserta bimwin pada Tahun 2017 mendapatkan kouta sebanyak 33 angkatan, pada tahun 2018 mendapatkan kouta sebanyak 10 angkatan, dan pada tahun 2019 mendapatkan kouta sebanyak 36 angkatan ditambah 4 angkatan bagi remaja usia nikah. ${ }^{37}$ Sementara jumlah peristiwa nikah pertahunnya se-Kota Makassar mencapai ribuan jumlahnya. Dengan demikian hendaknya semua calon pengantin diharuskan untuk mengikuti bimbingan perkawinan pranikah.

Kendala yang ketiga adalah belum adanya data pemetaan dari aspek sosiologi peserta bimwin, diketahui bahwa setiap diri seseorang tentunya mempunyai latar belakang yang berbeda-beda dengan gaya belajar yang berbeda-beda pula. Sehingga membutuhkan pemetaan lebih awal sebelum berhadapan dengan peserta yang bertujuan agar tujuan bimbingan dapat tercapai dengan baik. Dampak yang terjadi ketika sebuah pembelajaran tidak dipetakan, maka pembelajaran berjalan dengan dingin, tidak bergairah, dan statis yang berujung pada penurunan kualitas pemahaman para peserta. Untuk itu, dibutuhkan kemampuan untuk mengidentifikasi setiap peserta.

Kendala yang keempat adalah ketidak tepatan waktu dan kehadiran calon pengantin. Disiplin merupakan sebuah sikap yang merujuk pada karakter seseorang mengenai tanggung jawab serta caranya bersikap terhadap nilai-nilai yang dipercayainya. Salah satu kunci keberhasilan dalam sebuah proses bimbingan adalah kedisiplinan waktu, hal inilah yang menjadi kendala dalam pelaksanan bimbingan perkawinan pranikah karena peserta kurang disiplin dalam ketepatan waktu serta kehadiran mengikuti bimbingan.

2. Kendala Bimbingan Perkawinan Pranikah terhadap Peserta

Kendala yang dihadapi peserta selama mengikuti Bimbingan Perkawinan Pranikah adalah waktu bimbingan yang terlalu lama dan tidak fleksibel untuk para

\footnotetext{
${ }^{37}$ Sumber Data Bimas Islam Kementerian Agama Kota Makassar Tahun 2020.
} 
pekerja. Harapannya sebaiknya bimbingan pranikah bisa diadakan di hari libur kerja, sehingga pasangan yang memiliki pekerjaan tidak ada alasan lagi untuk tidak hadir ataupun pulang lebih awal.

\section{E. Kesimpulan}

Untuk menciptakan keluarga sakinah di wilayah Kecamatan Ujung Tanah Kota Makassar melalui bimbingan perkawinan pranikah dapat dilihat dari berbagai langkah dan upaya yang telah dilakukan pemerintah mulai dari terbitnya dasar hukum pelaksanaan, petunjuk pelaksanaan, unsur-unsur yang terkait seperti fasilitator, materi bimbingan, metode dan media yang digunakan. Melalui bimbingan ini maka kepercayaan diri calon pengantin untuk menjalani kehidupan berkeluarga juga meningkat. karena telah mendapat pengetahuan serta keterampilan tentang kehidupan berumah tangga, sehingga pasangan yang telah mengikuti bimbingan perkawinan pranikah merasa lebih siap menjalani kehidupan rumah tangga, peran bimbingan perkawinan pranikah dapat menciptakan keluarga sakinah.

Pelaksanaan bimbingan perkawinan pranikah di wilayah Kecamatan Ujung Tanah Kota Makassar mengalami beberapa kendala antara lain kendala terhadap fasilitator adalah media yang kurang mendukung, belum adanya keharusan kepada seluruh calon pengantin untuk mengikuti bimbingan perkawinan pranikah, belum adanya data pemetaan dari aspek sosiologi peserta bimwin dan ketidak tepatan waktu dan kehadiran calon pengantin. Adapun kendala terhadap peserta bimbingan adalah waktu bimbingan yang terlalu lama dan tidak fleksibel untuk para pekerja, sulitnya mengatur waktu para peserta dikarrnakan dilaksanakan pada hari bekerja sehingga tidak maksimal mengikuti materi bimbingan.

\section{Daftar Pustaka}

Arifin, M. Pedoman Pelaksanaan Bimbingan Penyuluh Agama. Jakarta: Golden Terayn Press, 1998.

Arsyad, Azhar. Media Pembelajaran. Jakarta: Raja Grafindo Persada, 2003. 
Azhari, Ari. "Pelaksanaan Kursus Pra-Nikah (Studi Komperatif di Kantor Urusan Agama Kec. Gondukusuma Kota Yogyakarta dengan Lembaga Pembinaan Persiapan Hidup Berkeluarga Kevikepan DIY)," Tesis. Yogyakarta: Prodi Hukum Islam Konsentrasi Hukum Keluarga, 2014.

Budiyanto, Dwi. Prophetic Learning. Yogyakarta: Pro-U Media, 2012.

Darwis, Rizal. Nafkah Batin Isteri dalam Hukum Perkawinan. Cet. 1; Gorontalo: Sultan Amai Press, 2015.

Departemen Pendidikan dan Kebudayaan RI. Kamus Besar Bahasa Indonesia, (Jakarta: PN. Balai Pustaka, 1989.

Kementerian Agama RI. Keputusan Direktur Jenderal Bimbingan Masyarakat Islam Nomor 379 Tahun 2018 tentang Petunjuk Pelaksanaan BImbingan Pranikah Bagi Calon Pengantin.

Kementerian Agama RI. Modul Bimbingan Perkawinan. Cet. 1; Jakarta: Subdit Bina Keluarga Sakinah Direktorat Bina KUA dan Keluarga Sakinah Ditjen Bimas Islam Kemenag RI, 2017.

Kementerian Agama RI. Peraturan Direktur Jenderal Bimbingan Masyarakat Islam NO. DJ.II/542 Tahun 2013 tentang Pedoman Penyelenggaraan Kursus Pra Nikah.

Kementerian Agama RI.. Peraturan Direktur Jenderal Bimbingan Masyarakat Islam Departemen Agama No. DJ. II/491 Tahun 2009 tentang Kursus Calon Pengantin.

Mubasyorah, "Konseling Pra Nikah dalam Mewujudkan Keluarga Bahagia.” Konseling Religi: Jurnal Bimbingan Konseling Islam, Vol. 7, No. 2, Desember 2016.

Nasution, Harun. Islam Rasional. Cet. 5; Bandung: Mizan, 1998.

Nofiyanti. "Layanan Bimbingan Pra Nikah dalam Meningkatkan Kematangan Emosional Berkeluarga." Prophetic, Vol. 1, No. 1, November 2018.

Prayitno, dkk. Dasar-Dasar Bimbingan dan Konseling.Jakarta: PT Rineka Cipta, 1999.

Sabri, Ahmad. Strategi Belajar Mengajar dan Micro Teaching. Cet. 2; Ciputat: PT Ciputat Press, 2007.

Suhertina. Pengantar Bimbingan dan Konseling di Sekolah.Pekanbaru: Suska Press, 2008 .

Walgito, Bimo. Bimbingan dan Konseling Perkawinan.Yogyakarta: Penerbit Andi, 2000 . 